is a conservationist, not in the sense that he seeks to protect wild life out of season, so that the mute and helpless creatures of wood and field can be indiscriminately maimed and slaughtered 'in season', but as a protector and preserver of all wild life in every season. In addition to being the author of numerous articles on natural history, he has had published several novels.

\section{Dr. Tweedie John Todd}

Dr. TweEdiE JoHn TodD, physician and naturalist, was born at Berwick in 1789, the son of the borough treasurer. He studied medicine at Edinburgh and for several years served as a surgeon in the Navy, chiefly in the East Indies and at the Cape of Good Hope, where he made some experiments on the electric ray (Torpedo), which were afterwards published in the Philosophical Transactions. He retired from the Navy in 1816, and after spending some years in Italy settled in Brighton, where he soon acquired an extensive practice. $\mathrm{He}$ was the author of several papers on natural history which were published in the Philosophical Transactions and the Journal of Science and Arts, such as "The Regeneration of Parts in the Aquatic Salamander" and "The Luminous Power of Some of the Lampyrides". His contribution to medical literature consisted of "The Book of Analysis. A New Method of Experience", in which he endeavoured to apply Baconian induction to medicine and the other natural sciences. For many years he was engaged in a series of microscopical researches on living animals illustrative of different parts of physiological and pathological science and especially of the processes concerned in the healing and regeneration of wounded and lost parts. He left a large collection of microscope slides at the time of his death, which took place on August 4, 1840.

\section{University Students and Compulsory Service}

Dr. RAYMond PrIestley, vice-chancellor of the University of Birmingham, in the course of a circular letter addressed to head masters of a number of schools in the Midlands, has pointed out that the age at which undergraduates will be called up for military service has been fixed by the Government at twenty years. This will enable many men to complete their university training before entering the Services. With the object of enhancing the value of such men to the national effort, it has been decided by the University of Birmingham that all future entrants will be required to choose one of the following options as part of their university course: (I) compulsory physical education for one year; or (2) two years service in the University contingent of the O.T.C. Those who choose the latter will be accepted for the O.T.C. only if they are approved by an interviewing board set up by the Military Education Committee, the main criteria being personality and power of leadership (latent or developed). Training in the O.T.C. will be carried out with the view of developing powers of leadership rather than training technical experts, and should prove of great interest and value to all who join, in whatever walk of life they may afterwards find themselves. The advantages of this general military training apply equally to those taking medical and dental courses, since the military background essential to an R.A.M.C. officer can be adequately acquired in this way. Those who obtain War Certificates A and B will have definite advantages when they are called up for military service; the scheme should go far towards ensuring that the best use is made of all those suitable as officers.

\section{Fire Risk from the Smashing of Filament Lamps}

ExpERIMENT shows that it is difficult to cause ignition of combustible material by means of smashing a filament lamp embedded in it. But the lampholder of a large lamp may rise to a fairly high temperature, high enough to explode certain compounds used for military purposes. It is well known that sudden breakage of a glass bulb may occur during heavy gunfire in a battleship or cruiser. It could also happen in a submarine when depth charges are exploding near it. This explains the interest now being taken in the United States Navy in fluorescent lighting for magazines and in other parts of a warship where explosives are handled. It is very difficult to set fire even to cotton-wool by smashing a lighted fluorescent lamp reposing on it.

A useful feature of the mercury fluorescent lamp is that it can easily be so graded as to emit the tone of blue light that is preferred for darkening a ship when in action at night. At present this reduced lighting effect is obtained by shading tungsten filament lamps and using a blue glass bulb, or one which has been sprayed in that colour. The Electrical Times of July 4 states that the U.S. Navy is having a series of experiments made with fluorescent lighting, and if it is found that this type obviates the danger due to filament lamps overheating in tropical atmospheres or when they are smashed by heavy gunfire, the mercury discharge type with fluorescent effect may find an extensive use in warships and elsewhere. It is also being recommended for mines, gasworks, petrol and benzine factories, hydrogen plant and all other places where the air is charged with explosive vapours or dust.

\section{Daylight Observation of Venus and Jupiter}

Dr. A. L. PEck, of Christ's College, Cambridge, writes: "In view of the astronomical notes in NaTuRE of July 27 , p. 128 , it may be of interest to record that two planets were picked out here with the naked eye on July 28, at 9.40 a.m. B.S.T.Venus (daylight observation of which is, of course, nothing unusual) and Jupiter. Observation of the latter was made possible by its proximity to the moon, with which it had been in conjunction a few hours before."

\section{British Museum (Natural History): Acquisitions}

The Zoological Department has received as a donation from Admiral Sir Sidney Bailey, a series of mounted heads of North American ungulates, including a very fine moose and some exceptionally good wapiti and caribou. The collection also contains a head of a Rocky Mountain goat. Another interesting 
gift to the same Department is a series of ten skulls with horns of African antelopes from the Dinder River District of the Sudan, presented by Mr. T. W. H. Dore. This collection contains, among other specimens, some skulls of Soemmer ring's gazelle and of the Sudan race of the roan antelope. The Department of Geology has acquired from the Committee of the Royal Literary and Scientific Institution, Bath, a collection of ninety-nine invertebrate fossils from the Mesozoic of Australia, including a number of type and figured specimens. The Trustees appreciate this recognition of the importance of housing type-specimens, other than those of local interest, in the National Collection.

\section{Beit Memorial Fellowships for Medical Research}

A MeEting of the Trustees of the Beit Memorial Fellowships for Medical Research was held on July 17. Prof. A. J. Clark, professor of materia medica in the University of Edinburgh, was appointed to the Advisory Board in succession to Prof. W. Bulloch, who resigned after twenty-nine years service. Dr. Paul Fildes was appointed honorary secretary on the resignation of Prof. T. R. Elliott from that post after ten years service. Out of the twenty-seven present fellows, nine have already been seconded from their fellowships at their own request for more direct service during the War.

The following elections were made, all with permission for each fellow to be seconded at any time for war duties: Senior Fellowship ( $£ 700$ a year): T. A. H. Munro, to continue his studies of inheritance in mental disorders, at the Royal Eastern Counties Institution, Colchester; Fourth Year Fellowships ( $\$ 500$ a year) : J. G. Chalmers, to continue his chemical studies of polycyclic hydrocarbons in experimental cancer formation, at the Research Department of the Glasgow Royal Cancer Hospital ; Dr. T. R. R. Mann, to extend his work on intracellular metallo-protein compounds, especially of red blood cells, at the Molteno Institute of Biology, University of Cambridge; Junior F'ellowships ( $\$ 400$ a year): M. Abercrombie, junior research fellow, Queen's College, Oxford, to study amputation neuromata and the degeneration and regeneration of mammalian nerves, at the Department of Zoology, University of Oxford; Dr. D. A. K. Black, research student of the Medical Research Council, to study metabolic and bone marrow changes in the repair of severe anæmias, at the Nuffield Department of Medicine, Oxford; Dr. G. C. Butler, 1851 Exhibition science research scholar, to study the purification and properties of gonadotrophic hormone from the pituitary gland, at the Department of Pathological Chemistry, University College Hospital Medical School, London; Dr. J. L. Madinaveitia, honorary research fellow in chemistry, University of Manchester, to study diffusing factors in bacterial filtrates and snake venoms, at the Department of Chemistry, University of Manchester ; Dr. S. M. Partridge, Lister Institute student in biochemistry, to study the chemical nature of the antigen of Shiga dysentery bacteria, at the Lister Institute of Preventive Medicine, University of
London ; D. Whitteridge, demonstrator in physiology, Oxford, to study electrical records from brain after concussion or severe injury, at the Nuffield Department of Surgery and the Department of Physiology, University of Oxford; P. C. Williams, research grantee of the Medical Research Council, to study pituitary hormones and their excretion in clinical pathological conditions, at the Courtauld Institute of Biochemistry, Middlesex Hospital, London.

\section{Announcements}

ThE Minister of Supply stated in the House of Commons on July 25 that due regard will be had to the provision of reasonable amounts of paper for educational, scientific, and technical publications.

According to Science of June 28, Prof. Peter Debye, of Berlin-Dahlem, has been appointed professor and chairman of the Department of Chemistry at Cornell University. Prof. Debye has been George F. Baker visiting lecturer in chemistry at Cornell University during the past term. His son, Peter Paul Debye, will be associated with Prof. Debye in research in the Baker Laboratory of Chemistry at Cornell. Prof. Jacob Papish, who has been chairman of the Department, will continue as vice-chairman. Dr. Bruno Rossi, formerly professor of physics in the University of Padua, research associate at the University of Chicago, has been appointed associate professor of physics at Cornell.

IT is announced that the Petain Government has dismissed M. Huismans, director-general of fine arts, M. Julien Cain, administrator of the Bibliothèque Nationale, M. Laugier, director of the national centre for scientific research, and M. Longchambon, director of scientific research, who are said to have abandoned their posts under the previous French Government without justification.

The Council of the University of Birmingham has instituted a scheme for family allowances for members of staff whose salaries do not exceed $£ 700$ per annum. The allowance, for salaried members, is at the rate of $£ 25$ per annum for each child. The wage-earning staff receive an allowance of $2 s .6 d$. per week for each child less than sixteen years of age. The scheme takes effect as from February last.

IN 1920, Miss L. Jones-Bateman of Cae Glas, Abergele, presented to the Royal Horticultural Society a valuable silver-gilt replica of the Warwick Vase to be used for the encouragement of fruit production. It is accordingly decided to offer it triennially for original research in fruit culture. Candidates should submit accounts of their work by October 31. The work dealt with should have been mainly carried out by the candidate in the United Kingdom, and mostly during the past five years.

Erratum. Nature, July 20, p. 101, col. 2, paragraph on "Precautions against American Foul Brood in Bees", line 13, for "American" read "European". 